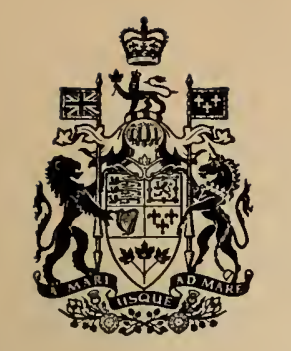

Publication 955

November 1960
CAIVIANAGRICLLTURE LIBRARY BIBLIOTHEQUE CANADIENNE DE L'AGRICURTURE

\title{
GRASS SILAGE for \\ BEEF CATTLE
}

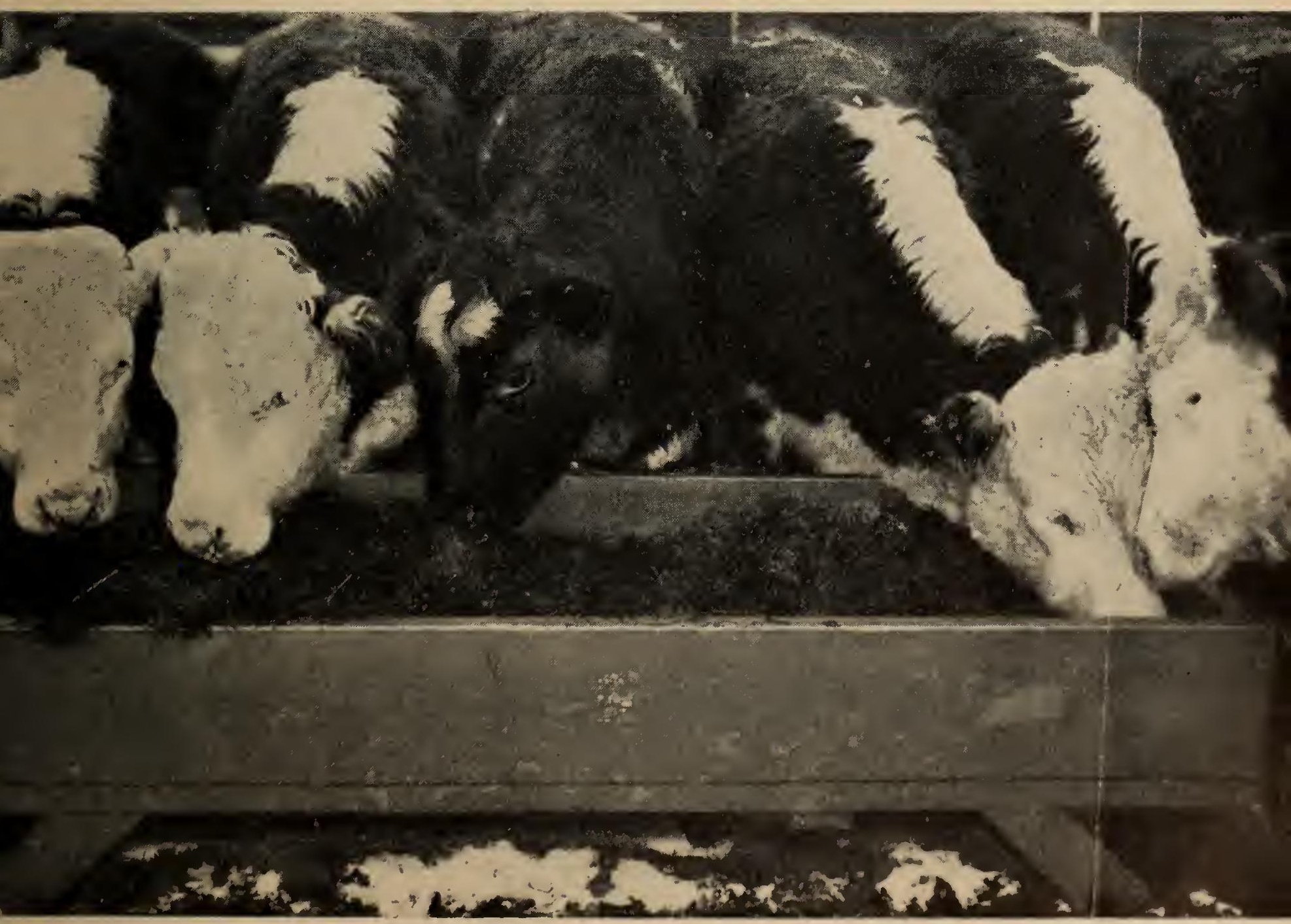

$30 . \mathrm{R}$

RESEARCH BRANCH, CANADA DEPARTMENT OF AGRICULTURE

D.ch 2125

Rev.1960

6.2 
First Printing. . . . . June 1955

Revised........... Oct. 1960

Copies of this publication may be obtained from

InFormation Division

CANADA DEPARTMENT OF AGRICULTURE

Ottawa, Ontario.

ROGER DUHAMEL, F.R.S.C.

QUEEN'S PRINTER AND CONTROLLER OF STATIONERY OTTAWA, 1960

Cat. No. A53-955 


\section{CONTENTS}

PAGE

Nutritive value of grass silage. . . . . . . . . . . . . . . . . . 5

Quality and palatability ....................... 6

Effects of preservatives on feed value .................. 6

Feeding methods. . . . . . . . . . . . . . . . . . . 7

Grass silage for the breeding herd ................... 9

Grass silage for wintering beef calves. . . . . . . . . . . . . . 10

Grass silage for wintering yearlings. . . . . . . . . . . . . . 10

Grass silage for fattening cattle...................... 11

Summary. . . . . . . . . . . . . . . . . . . . . . 13 



\section{GRASS SILAGE FOR BEEF CATTLE}

\section{BY P. E. SYLVESTRE ${ }^{1}$ AND E. MERCIER ${ }^{2}$}

In recent years, great interest has developed in preserving meadow crops as silage rather than as hay. This interest has arisen from an increasing appreciation of the importance of high-quality roughage in the winter feed of all classes of cattle and from the difficulty of making good hay in unfavorable weather. New developments in harvesting machinery have reduced the cost and the difficulty of handling heavy, green material.

The term 'grass silage' is generally used for the product obtained from green forage crops that have fermented in silos. It is often called hay-crop silage because most of the forage crops ensiled would otherwise be harvested as dry hay. Grass silage may contain legumes or grasses, or both in almost any ratio. More specific terms such as alfalfa silage and alfalfa-molasses silage are sometimes used to indicate the particular material ensiled or the method of preservation. 'Grass silage' is also used for silages made from cereal crops, peas, vetches, soybeans, or a mixture of these crops. In this publication 'grass silage' is used for a mixture of grass and one or more legumes.

\section{NUTRITIVE VALUE OF GRASS SILAGE}

Grass silage varies widely in feed value. For example, it may vary from about 70 to 84 per cent in moisture content, depending on the forage mixture, the stage of maturity, and the weather when the crop was ensiled. This means that cattle may get roughly 1.5 times as much dry matter per pound of feed from a silage with 70 per cent moisture as from one with 80 per cent. A moisture content of about 74 per cent is best for producing palatable, good-quality silage. Cattle that feed on such silage will take in enough dry matter.

The protein content of grass silage, on a dry basis, may vary from about 8 to 19 per cent, depending on the forage mixture and the stage of maturity at which it was ensiled. Generally, silages high in legumes contain more protein than those high in grass. Cutting at an immature stage yields a silage higher in protein than cutting at greater maturity.

Grass silage is lower in net energy and digestible nutrients than well-eared corn silage because of the considerable amount of grain in the latter. It is slightly lower in digestible nutrients than well-cured hay from the same forage. However, these differences in favor of corn silage and hay may be offset by the higher protein content of grass silage.

Grass silage is high in carotene and, when forming part or all of the roughage ration, will provide for the vitamin A needs of all classes of beef cattle. On the other hand, grass silage is low in vitamin D, especially if the silage is made without wilting the material after cutting. Hence, a vitamin $\mathrm{D}$ supplement may be advisable if animals are wintered indoors.

${ }^{1}$ Research Officer, Animal Research Institute, Central Experimental Farm, Ottawa, Ontario.

${ }^{2}$ Superintendent, Experimental Farm, Lennoxville, Quebec;now Deputy Minister, Quebec Department of Agriculture. 
Grass silage, corn silage, and hay differ little in phosphorus content. However, grass silage contains three or four times as much calcium as corn silage does, and about the same amount as hay made from the same material.

\section{QUALITY AND PALATABILITY}

Grass silage of good quality has a high feed value and is readily accepted by stock. Chemists have found that these two attributes are associated with a high content of lactic acid, a low content of ammonia and butyric acid, a lower content of fiber than hay, and a moisture content of about 74 per cent. As a cattle feeder cannot have chemical analyses made frequently, he must use other means to estimate the quality of his grass silage. Odor and color, although not infallible, appear most practical for that purpose.

Good silage is usually greenish brown or yellowish brown and has a mildly sweet and pleasant odor. Such silage is rich in lactic acid. If silage is yellow and has an offensive and permeating odor that clings to the clothing and hands, it is likely to be poor in quality because it contains large amounts of butyric acid and tends to be slimy. A dark-brown color accompanied by the characteristic odor of tobacco is a sure sign of overheating. Overheated silage is readily eaten by cattle but it has lost some of its feeding value. Black silage is rotted and is unfit for feed; such material is generally found at the surface and near the wall of the silo. Moldy silage is also unfit for feed.

Palatability is not a sure guide to quality, although it is important. Good grass silage is always consumed readily, but cattle may relish, at least for a time, silage with an extremely offensive odor. Palatability helps in obtaining greater consumption with less waste, without addition of more palatable feeds as a disguise.

\section{EFFECTS OF PRESERVATIVES ON FEED VALUE}

To promote favorable fermentation, a preservative such as molasses or grain is sometimes added to the crop at the time of ensiling. These ingredients increase the feed value of grass silage, but not in proportion to the quantity added since some is lost in the fermentation process. About 75 per cent of the molasses added remains in the silage. When grains are added instead of molasses, the percentage remaining is a little higher. Also, grains help to reduce the moisture content of the silage. Chemical preservatives such as sulphur dioxide, sodium metabisulphite, and the various acids do not increase the feed value. However, they may increase the palatability and quality of the silage by reducing losses from fermentation.

\section{Hand Feeding}

\section{FEEDING METHODS}

Grass silage spoils rapidly when exposed to the air at a high temperature; if exposed long enough to a low temperature, it may freeze hard. Under both conditions, some losses are bound to occur. To reduce these losses bring the silage to the feed room before every feeding or at least every day; this reduces the time of exposure to the air and to the unfavorable temperature. If open pits and horizontal silos are exposed to snow or frost, reduce losses and save labor by covering the open cut. A tarpaulin or jute bags sewn together provide a suitable cover for this purpose.

Although grass silage of good quality is generally eaten readily, cattle may refuse it at first. To accustom such animals to silage, put a little on top of their 
hay. While eating the hay, the animals eat some of the silage and soon acquire a taste for it. Later on, reduce or remove the hay entirely. If silage is somewhat unpalatable, spread meal over it to get it eaten readily. If you feed a grain supplement, place it on top of the silage to obtain more rapid and greater consumption of the silage.

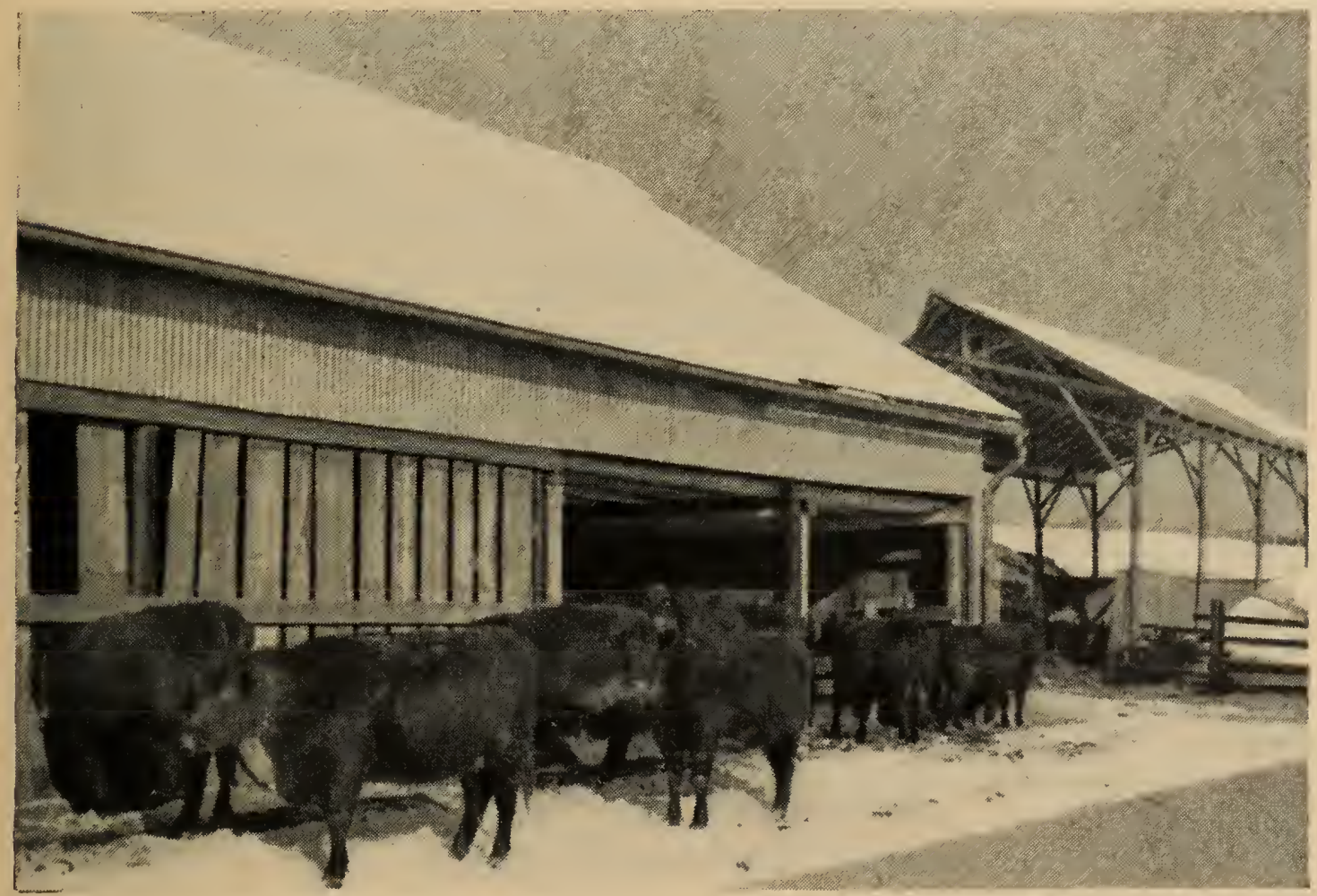

Figure 1. Proper location of the silo is important in self-feeding.

You may feed silage once or twice daily, depending on the quantity to be eaten by the animals and the labor available on the farm. If you feed the silage inside with the temperature above freezing, feed it once or twice, whichever is more convenient. If you feed it outside in freezing weather, feed it twice a day so that the animals will clean up the smaller amount offered in each feeding before it freezes. However, if you feed a small amount of silage, one feeding at mid-day, when the temperature is highest, is satisfactory.

\section{Self-feeding}

The laborious task of removing grass silage from horizontal silos has prompted the development of self-feeding devices. However, the success of this method of feeding in Canada depends on a number of factors, the more important being the quality of the silage and the exposure of the silo to freezing rain, snow, and frost.

Studies at the Central Experimental Farm, Ottawa, with a horizontal silo in a cattle yard (Figure 2) have shown that self-feeding presents little difficulty if the moisture content of the silage is not above 75 per cent, and the outside temperature does not drop below $-10^{\circ} \mathrm{F}$. Under these conditions, labor was reduced by about 75 per cent, but more silage was wasted than with hand-feeding.

At the Experimental Farm, Lennoxville, 50 beef cows were self-fed successfully for four winters from a roof-covered horizontal silo 20 feed wide (Figure 1). Although boss cows sometimes crowded the others at the feeding gate, no abortions occurred and all cows wintered in good flesh. 


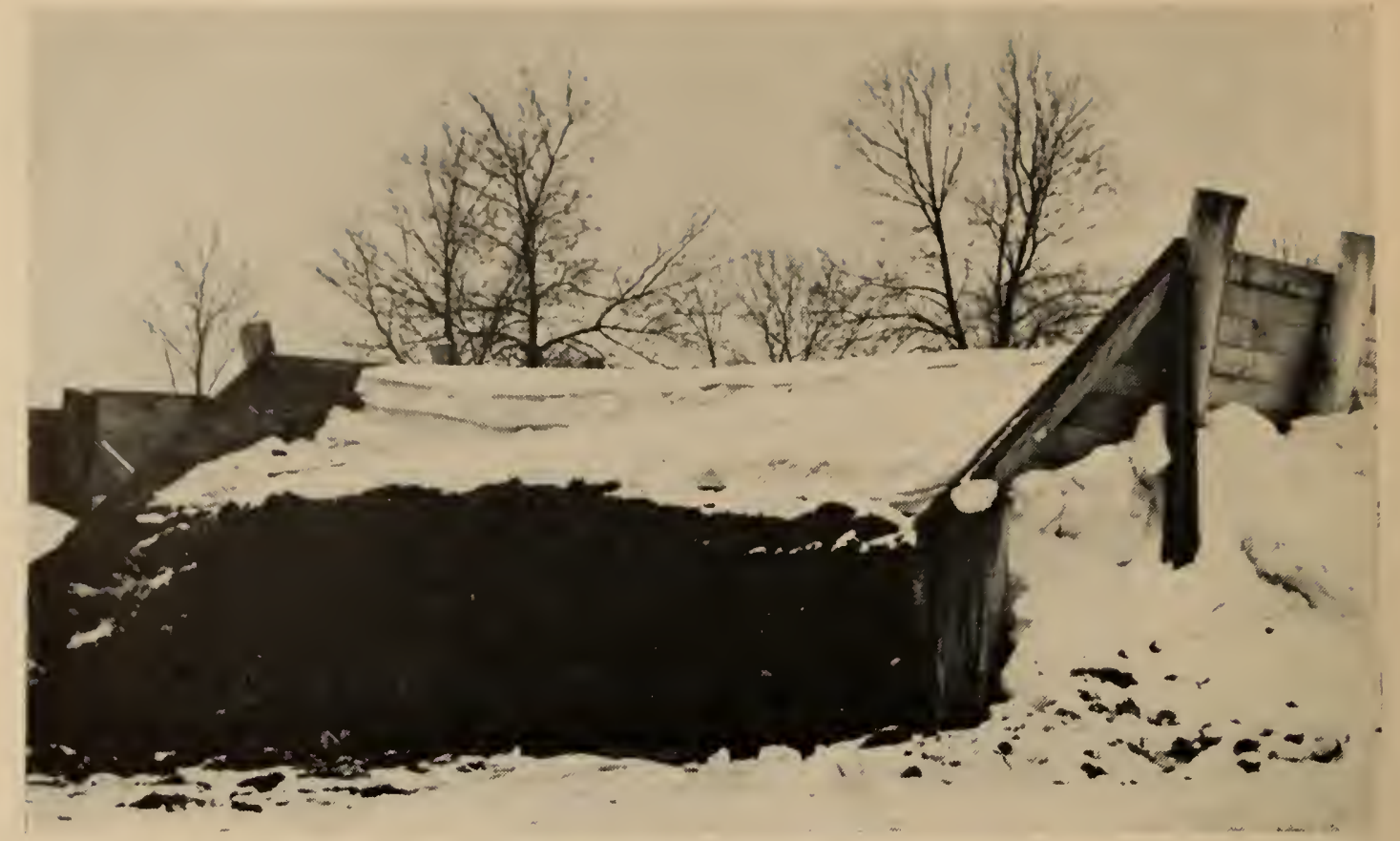

Figure 2. A horizontal silo is a relatively cheap means of storing grass silage.

Under severe winter conditions, take the following precautions to ensure success with self-feeding and to reduce labor:

1. Make sure that the silo is well drained, easily reached by the animals, and protected as much as possible from snow and cold.

2. See that your silage is of good quality and has a moisture content of not more than 75 per cent.

3. Chop the silage since long silage is seldom loose enough for the animals to eat directly from the pile.

4. Whenever possible, bank the silo walls with earth or other material to reduce freezing of the silage in contact with the walls. In addition, protect the surface cut of the silage from frost and snow.

5. Do not let loose silage accumulate on the floor of the silo and spoil.

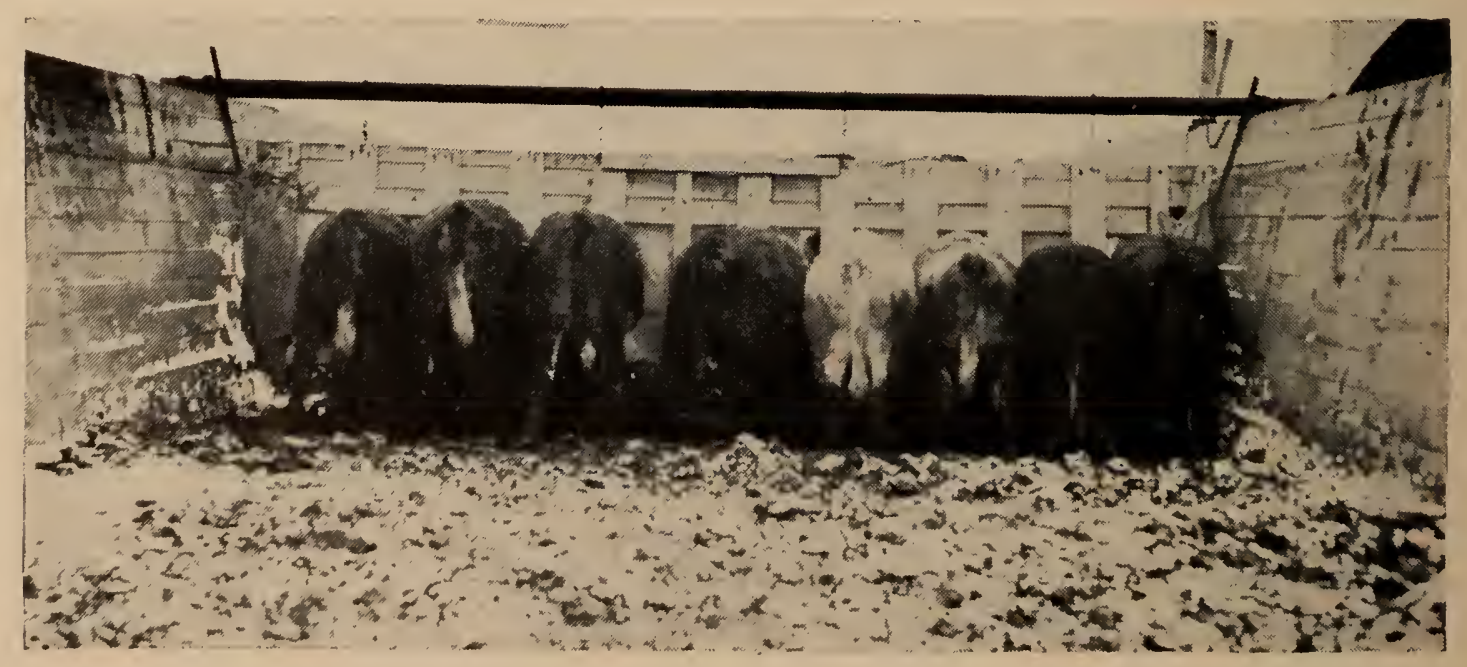

Figure 3. A movable feeder gate of the stanchion type, suspended from a roller bar, helps to control feeding and reduce waste in horizontal silos. 
The equipment necessary for self-feeding obviously varies with the location, shape, and construction of the silo. In experiments at Ottawa and Lennoxville, the following equipment was found satisfactory when used with horizontal silos (Figure 3). A movable stanchion-type feeder-gate is suspended across the width of the silo by a roller-bar resting on the wall. The gate is fastened so that it cannot be moved back and forth by the animals. The gate is set so that only 7 to 8 inches of fresh silage is within reach of the cattle. This ensures that silage that drops is eaten before it has had time to freeze, dry, or spoil. The adjustment of the gate is important as it controls the amount of spoilage and to a great extent the amount of silage consumed.

If the silo is in the open, spread a tarpaulin, or boards and straw or cotton bags, over the gate openings; this considerably reduces losses from snow and frost. Always having some animals feeding reduces losses due to freezing or silage becoming stale. To attain this objective allow three to four animals to 24 inches of feed rack.

\section{GRASS SILAGE FOR THE BREEDING HERD}

Grass silage may be fed alone or with hay to wintering pregnant beef cows. When fed alone, grass silage is satisfactory if it is of good quality and the moisture content is not above 80 per cent. At the Central Experimental Farm, Ottawa, pregnant beef cows lost weight when fed only grass silage. However, weight and vigor of the calves were evidently not affected, and all the cows regained their weight on pasture. The cows ate an average of 81 pounds of silage daily, or about 16.6 pounds of dry matter; this about meets the needs of beef cows over 1,000 pounds in live weight. When grass silage is the only feed, give the cows all they will clean up two or three times a day to make sure that they take in enough dry

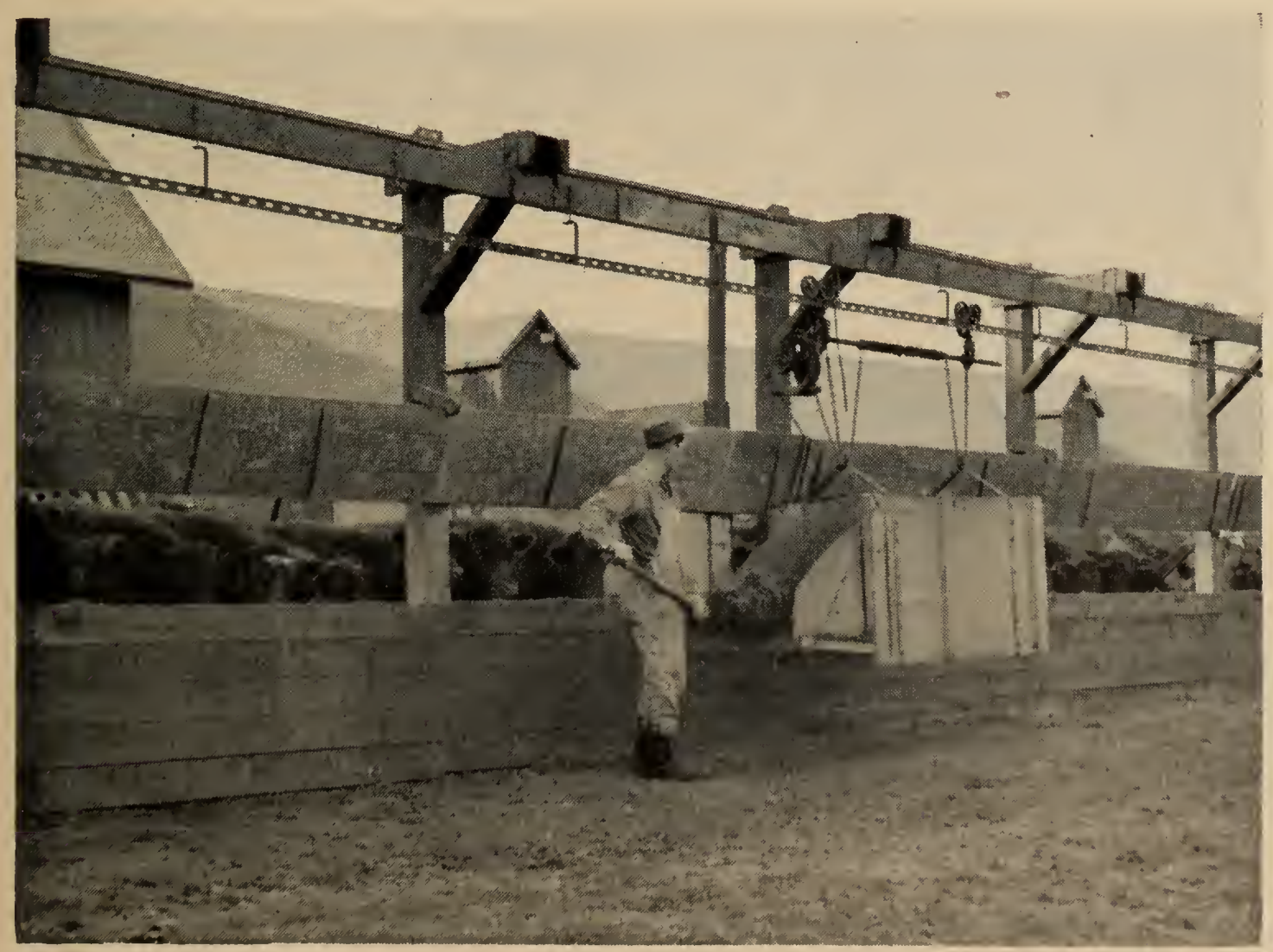

Figure 4. An easy way of feeding grass silage outside. 
matter and net energy. In addition, provide good pasture in summer and fall so that if the cows lose condition they may regain their weight before the next winter.

Feeding hay with grass silage appears to be better than feeding grass silage alone, according to experiments at Ottawa and Lennoxville. Cows receiving hay and grass silage wintered in better condition than those on the silage alone and did not crave dry feeds. The proportions of grass silage and hay may vary considerably according to the availability of the two roughages. However, when the two are equally abundant, 1 to $1 \frac{1}{4}$ pounds of hay with 3 to 4 pounds of grass silage per 100 pounds of live weight provides a good ration.

In an experiment at Ottawa, grass silage was slightly inferior to corn silage when each was fed with hay to beef cows. Two groups were fed the same amount of hay. In addition, one group received grass silage and the other corn silage. The amount of each type of silage was so adjusted that each group of cows ate the same amount of dry matter. The cows fed corn silage gained slightly while those fed grass silage lost weight. Calves from the two groups were similar in quality.

\section{GRASS SILAGE FOR WINTERING BEEF CALVES}

Beef calves not intended for immediate fattening need enough feed for normal growth. Experiments have shown that a daily gain of 0.8 to 1 pound is adequate and that a little grain is necessary with any roughage.

At the Experimental Farm at Lennoxville, grass silage as the only roughage, when fed with a small amount of grain, was somewhat better than hay and the same amount of grain. The higher protein content of the silage, on a dry basis, is probably the reason for this superiority. In the 120-day experiment, calves weighing 500 pounds at the beginning ate 25 pounds of silage per head daily.

To feed calves grass silage as the only roughage, begin gradually. At first, give 10 to 12 pounds daily in two feeds, and then increase the amount gradually until the calves receive all they will clean up in about one hour twice a day. To obtain better and more rapid consumption, place the grain on top of the silage at each feed.

Calves receiving grass silage as the only roughage may sometimes eat the straw used for bedding. This does not indicate that feeding hay is necessary for best gain. At Lennoxville, grass silage along with 2 pounds of grain per head daily was consistently better than hay, grass silage, and 2 pounds of grain per head daily. On the other hand, adding silage to a hay and grain ration improves it somewhat, as shown by tests at Lennoxville. When grass silage was fed with hay the calves ate 6.8 pounds of hay, 16.8 pounds of silage, and 2 pounds of grain per head daily.

At Ottawa, grass silage was found to be equal to corn silage when fed with a small amount of hay and grain. Four pounds of hay and 1.75 pounds of grain per head were fed daily to each of two groups. The amounts of the silages fed were such that each group received the same amount of dry matter daily. Both groups gained 0.8 pounds daily, and the calves were similar in condition and outcome. Each calf ate an average of 18 pounds of silage daily.

\section{GRASS SILAGE FOR WINTERING YEARLINGS}

Yearling cattle, steers, and heifers can be wintered satisfactorily on grass silage of good quality as the only feed. However, if the silage is high in moisture, they will be unable to eat enough to meet their energy requirements. Yearling 
cattle should eat from 65 to 70 pounds daily, or all they will clean up twice daily. If the silage is relatively low in moisture, full feeding will result in daily gains of $\frac{1}{4}$ to $\frac{1}{2}$ pound.

In wintering yearling heifers without grain, substitution of grass silage for part of the hay ration has given good results in experiments at Lennoxville. Gains were twice as great with the two roughages together as with either one alone. These roughages evidently complement each other, the hay furnishing extra energy and the silage extra protein and minerals. The ratio of silage to hay may vary considerably and still be satisfactory. Good results have been obtained by feeding as little as 3.5 pounds of hay with as much as 68 pounds of silage. However, it is better to feed more hay, especially if the silage is high in moisture.

Feeding a small amount of grain with grass silage alone, or with grass silage and hay, has given remarkable gains. At Lennoxville, steers fed 2 pounds of grain daily with grass silage and hay gained 1 pound daily. At Ottawa, similar steers fed grass silage as the only roughage plus 4 pounds of grain gained 1.47 pounds daily. It may be necessary to feed a small amount of grain, 2 to 3 pounds per head daily, when hay is not available and the silage is high in moisture. A little grain may also be economical, even with a good roughage ration, in preparing cattle for finishing on pasture in July or August to take advantage of a strong market. However, the economy of this procedure is doubtful with cattle to be marketed in October; cattle fed grain in winter, in addition to a good roughage ration, do not generally gain so rapidly on pasture as those fed no grain.

\section{GRASS SILAGE FOR FATTENING CATTLE}

With grass silage as with other roughages, grains are necessary to obtain proper finish. As the nutrients in grains generally cost more than those in roughages, the quality and amount of each in the ration should be such as to allow the largest gain at the lowest possible cost. As mentioned previously, grass silage is relatively high in protein but low in energy. On the other hand, home-grown grains are cheap, energy-producing feeds. Therefore, when the two are fed together they form a satisfactory fattening ration without the addition of expensive protein supplements.

\section{Fattening Fed Calves}

The fattening of weanling calves requires considerable grain. Roughages should also be fed but in small amounts, since these young animals cannot handle much bulky feed. Grass silage of good quality may replace hay, or may be fed with hay. It may also replace corn silage, almost pound for pound. When using grass silage as the only roughage, feed no more than 20 pounds per head daily at any time during the fattening period. When using grass silage with hay, feed only 8 to 12 pounds per head daily, depending upon the amount of hay fed.

Good results have been obtained from feeding 8 pounds of grass silage and 2 pounds of hay daily from the time the calves are on a full feed of grain until they are marketed. As the calves grow and eat more, increase the grain rather than the roughage.

\section{Fattening Yearling Steers}

Grass silage of good quality fed as the only roughage is at least equal to hay, if not superior, for yearling steers on full grain feeding. In experiments at 
Ottawa, steers fed grass silage as the only roughage gained more (1.9 pounds daily) than those fed hay (1.6 pounds), on a smaller amount of feed on a drymatter basis. The finish was as good as for those fed hay alone.

In another experiment, steers fed 8 to 10 pounds of grain per head per day plus all the griss silage they would clean up gained between 1.8 and 2.4 pounds daily, 8.4 to 8.2 pounds of dry matter being required for 1 pound of gain. Feeding larger amounts of grain gave little extra gain. On the other hand, 4 pounds of grain per head daily with grass silage gave the remarkable daily gain of 1.5 pounds, only 9.8 pounds of dry matter being required per pound of gain, or 1.4 pounds more dry matter per pound of gain than for those receiving 8 pounds of grain. Feeding 4 pounds of grain daily might be advantageous where silage is abundant and it is desired to take advantage of a rising market in the late spring or early summer.

Grass silage may replace part of the hay fed and improve the ration. Steers fed 5 pounds of hay, 20 pounds of silage, and 10 pounds of grain gained more rapidly (1.74 pounds daily) than steers on hay and grain (1.59 pounds daily). However, supplementing grass silage with hay does not improve the ration except when the silage is very high in moisture or poor in quality. The ratio of grass silage to hay may vary with the roughages available. If both are plentiful, 1 pound of hay to 3 to 4 pounds of silage per 100 pounds of body weight is satisfactory.

Grass silage equals corn silage pound for pound, when both are fed with hay and a full ration of grain. However, on a small amount of grain, steers on corn silage generally gain more rapidly than those on grass silage.

\section{Fattening Two-year-old Steers}

As two-year-old steers can handle larger amounts of roughage than younger cattle, grass silage may be used for a larger proportion of the nutrients required for the fattening process. Agricultural scientists in England and Ireland have fattened bullocks three years of age on grass silage alone. The silage was made with immature forage and was similar in feeding value to a grain concentrate. In Canada more mature forage is generally used to make silage, and grain must be fed to obtain proper finish. Steers coming off pasture in good condition can be finished in 60 to 90 days on 10 to 12 pounds of grain a day and all the silage they will clean up. However, one might better feed steers that are to be marketed in the spring on roughage alone for half the period and then finish them rapidly on a full feeding of grain. This procedure is generally considered more economical than the continuous moderate feeding of grains.

Depending on the size of the animals, two-year-old steers should eat between 75 and 90 pounds of silage daily when it is fed as the only roughage, or 50 to 60 pounds of silage and 8 to 10 pounds of hay when both roughages are fed. Reduce each of these amounts of roughage when grain feeding starts. 


\section{SUMMARY}

1. Grass silage is made from meadow crops and any other green forage except corn, but usually from legumes or grasses or a combination of both.

2. Good grass silage has a mildly sweet and pleasant odor; it is greenish brown or yellowish brown and has a moisture content of about 74 per cent.

3. Good grass silage is relatively righ in protein, calcium, and carotene. It is lower in digestible nutrients, and net energy, than corn silage. Good grass silage is slightly higher in protein than well-cured hay, but somewhat lower in digestible nutrients and net energy.

4. Good grass silage is satisfactory as the only feed for pregnant beef cows. Better results are obtained if a small amount of hay is fed with the silage.

5. Beef calves winter well on 2 pounds of grain daily and all the silage they can eat. Grass silage improves a ration of grain and hay for calves.

6. Yearling cattle maintain their weight on good grass silage alone. Substituting hay for part of the silage gives slight gains. Adding 2 pounds of grain per animal daily may give up to 1 pound of gain per day.

7. For fattening cattle, grass silage gives results just as good as or better than corn silage and hay when the animals, in both cases, are full-fed on grain. Grass silage may be fed as the only roughage or with hay. When the silage is fed with cereal grains, the more expensive protein supplements are unnecessary. 

